\title{
KONTROVERSI KETERLIBATAN SOEHARTO DALAM PENUMPASAN G30S/PKI 1965
}

\author{
Oleh: Andrianto* \\ ${ }^{*}$ Dosen Program Studi Pendidikan Sejarah FKIP Universitas Veteran Bangun Nusantara Sukoharjo
}

\begin{abstract}
ABSTRAK
Gerakan 30 September (disingkat G.30.S/PKI) atau Gestapu (Gerakan September Tiga Puluh) dan Gestok (Gerakan Satu Oktober) adalah sebuah peristiwa yang terjadi Kamis malam tanggal 30 September menjelang tanggal 1 Oktober 1965 dan enam Perwira Tinggi militer Indonesia menjadi korban. Masalah penelitian ini adalah Bagaimanakah kontroversi keterlibatan Soeharto dalam penumpasan G 30 S/PKI 1965? Penelitian ini menggunakan metode historis, yaitu kegiatan mengkaji suatu masalah secara teliti dan teratur, dengan cara menyusun gagasan yang terarah dan terkonsep untuk memecahkan permasalahan yang hidup dan berguna bagi peneliti. Hasil penelitian: (1) Kontroversi merupakan perbedaan pandangan yang muncul mengenai Gerakan 30 September 1965 G.30.S/PKI adalah peristiwa pembunuhan yang terjadi pada tanggal 30 September menjelang 1 Oktober 1965. (2) Pada 30 September 1965, enam Jendral Senior dan beberapa orang lainnya dibunuh dalam upaya kudeta yang disalahkan kepada para pengawal istana. (3)Pengangkatan Mayjend Soeharto sebagai panglima operasi pemulihan keamanan dan ketertiban serta pembentukan komando operasi pemulihan keamanan dan ketertiban (Kopkamtib).
\end{abstract}

Kata Kunci: Sejarah kontroversi, G30S/PKI.

\section{A. PENDAHULUAN}

Sebelum meletusnya pemberontakan G30S (Gerakan 30 September) tanggal 30 September 1965, Partai Komunis Indonesia (PKI) telah berhasil menjadikan dirinya sebagai salah satu partai yang terbesar di Indonesia. Dengan pimpinan dan anggotaanggotanya yang militan, didukung pula oleh negara-negara besar komunis lainnya. Pimpinan Partai Komunis Indonesia (PKI) telah merangkul Presiden Soekarno, mempengaruhi dan membina sejumlah besar perwira-perwira Angkatan Bersenjata Republik Indonesia (ABRI) dan menguasai sebagian besar organisasi-organisasi nasional vital yang ada di negara kita. Selain usaha membina sejumlah perwiraperwira Angkatan Darat (AD), juga menyebar perpecahan di kalangan Angkatan Darat (AD) dan membuat fitnahfitnah untuk menyingkirkan pimpinan Amerika Serikat (AS) yang ada dengan menggantinya dengan tokoh-tokoh perwira yang pro-komunis. Usaha PKI itu mencapai puncaknya pada akhir bulan September
1965, dengan meletusnya pemberontakan Gerakan 30 September Partai Komunis Indonesia atau G.30.S/PKI tahun $1965 \mathrm{di}$ bawah pimpinan Letnan Kolonel Untung dan Brigadil Jenderal Supardjo, (Sudirjo, 1977:50).

Gerakan 30 September (dahulu juga disingkat G.30.S/PKI), Gestapu (Gerakan September Tiga Puluh), Gestok (Gerakan Satu Oktober) adalah sebuah peristiwa yang terjadi Kamis malam tanggal 30 September menjelang tanggal 1 Oktober 1965 dan enam perwira tinggi militer Indonesia menjadi korban (Samsudin, 2004:44).

Menurut Sucipto, (2013:112-113) sejak pertengahan Agustus 1965, kesehatan Soekarno menurun, sampai menjelang terjadinya Gerakan 30 September telah beredar kabar sakit parahnya Soekarno. Menurut Roeder, (1987:35) telah menjadi kebiasaan sebelumnya bahwa apabila Panglima Angkatan Darat berhalangan, Panglima 
Komando Strategis Angkatan Darat (KOSTRAD) ditunjuk sebagai penjabatnya.

Menurut Sucipto, (2013:125) mengingat Soekarno adalah Pemimpin Besar Revolusi (PBR), beliau mengumumkan dan memanggil semua panglima angkatan bersenjata bersama wakil perdana menteri dan pejabat penting lainnya. Pimpinan angkatan darat langsung berada di tangan beliau dan tugas-tugas sehari-hari dijalankan oleh Mayjen Pranoto Reksosamodra, sedangkan Mayjen Soeharto Panglima Komando Strategi Angkatan Darat (KOSTRAD) ditunjuk untuk melaksanakan pemulihan keamanan dan ketertiban. Maka dari itu Soeharto menjadi sosok penting dalam penumpasan pemberontakan 30 September yang melibatkan Partai Komunis Indonesia (PKI).

Adapun pandangan lain menyatakan

Soeharto terlibat dalam pemberontakan itu, Kolonel Latief tahanan politik Orde Baru yang menjabat Komandan Brigade Infanteri I Kodam V Jaya, saat peristiwa Gerakan 30 September tahun 1965 meletus, Soeharto adalah seseorang yang mengetahui rencana peristiwa Gerakan 30 September tahun 1965. Pemberontakan G.30.S/PKI telah dilaporkannya kepada Soeharto pada 28 September 1965, dua hari sebelum penculikan para jenderal terjadi. Tetapi Soeharto selaku Panglima Komando Strategis Angkatan Darat (KOSTRAD) tidak menggagalkan peristiwa yang membahayakan Soekarno selaku presiden.

Menurut Wertheim dalam Sucipto, (2013:174) mengatakan bahwa tanggal 1 Oktober 1965, terjadi pertemuan antara Soeharto, Latief dan Untung (pimpinan penculikan ketujuh Jenderal). Asumsinya, dengan pertemuan itu, Soeharto sebenarnya memahami tentang rencana tersebut, karena melihat kedekatan dan pertemuan yang terjadi. Tetapi para ahli sejarah dan politik yang berpendapat bahwa Soeharto bukan tipe orang yang pintar yang bisa merancang kudeta secara sistematis. Soeharto hanyalah orang yang sudah tahu kejadian tersebut, melalui pertemuannya dengan Untung dan Latief. Sehingga ia menjadi orang yang paling siap menghadapi sesuatu yang akan terjadi. Kesiapan Soeharto inilah yang menjadi senjata yang untuk menumpas Partai Komunis Indonesia (PKI) dan merebut kekuasaan dari Soekarno (Roeder,1987:74).

Menurut Pambudi, (2006:202) belum jelas siapa dalang Gerakan 30 September, namun implikasi yang ditimbulkannya sangatlah jelas, Mayor Jenderal Soeharto berhasil mengambil alih Komando Strategis Angkatan Darat (KOSTRAD) sepeninggalan Letnan Jenderal Ahmad Yani yang gugur dalam usaha perebutan kekuasaan di Lubang Buaya. Setelah Mayor Jenderal Soeharto berhasil menumpas komplotan Untung, target berikutnya membersihkan kekuasaan Presiden Soekarno. Penekanan Presiden untuk membubarkan Partai Komunis secara resmi, adalah jalan dipilihnya.

\section{B. METODE PENELITIAN}

Metode Penelitian merupakan rangkaian cara atau kegiatan pelaksanaan penelitian yang didasari oleh asumsiasumsi dasar, pandangan-pandangan filosofis dan ideologis, pertanyaan dan isuisu yang dihadapi (Sudharmono, 2010: 52).

Menurut Priyadi, (2012:67-70) Untuk menghasilkan suatu karya atau kisah sejarah seseorang harus berpegangan pada metode historis, ada beberapa langkah perlu di patuhi oleh seorang peneliti.

\section{Tahap Heuristik}

Tahapan pertama yaitu mencari dan mengumpulkan sumber yang berhubungan dengan topik yang akan dibahas dalam penelitian ini, yakni "Keterlibatan Soeharto dalam penumpasan G.30.S/PKI". Secara harfiah, heuristik berasal dari bahasa Yunani yang berarti menemukan. Jadi heuristik adalah tahap untuk menemukan sumber-sumber sejarah sehingga diperoleh 
data yang mendukung dan relevan terhadap judul penelitian yang akan di teliti. Untuk memperoleh data-data tersebut, seorang peneliti harus melakukan pengumpulan pustaka, arsip-arsip atau dokumen di perpustakaan maupun melakukan tinjauan langsung ke lapangan.

\section{Tahap Interpretasi}

Kemudian dilakukan interpretasi atau penafsiran terhadap fakta sejarah yang diperoleh dari arsip, buku-buku yang relevan dengan Keterlibatan Soeharto terhadap G.30.S/PKI. Interpretasi adalah penafsiran terhadap fakta sejarah yang kemudian dirangkai menjadi sebuah kesatuan yang harmonis serta masuk akal. Dalam tahap interpretasi harus bersifat objektif. Selain itu juga harus bersifat selektif, artinya bahwa semua fakta tidak dimasukan semuanya melainkan diambil yang sesuai dengan topik yang akan dibahas (Priyadi, 2012:69).

\section{Tahap Historiografi \\ Menurut Priyadi,}

historiografi merupakan tahap dalam penulisan sejarah. Ini merupakan tahap terakhir dari serangkaian tahap penelitian sejarah. Penulisan sejarah harus searah atau sesuai dengan interpretasi yang dilakukan. Menurut Moleong dalam Margono, (2009:36) Penelitian Kualitatif adalah prosedur penelitian yang menghasilkan data deskriptif berupa katakata tertulis atau lisan dari orang-orang dan perilaku yang dapat diamati (Margono, 2009:18).

\section{HASIL PENELITIAN DAN PEMBAHASAN}

Pemberontakan PKI tanggal 30 September 1965 bukanlah pertama kali bagi PKI. Sebelumnya, pada tahun 1948 PKI sudah pernah mengadakan pemberontakan di Madiun. Pemberontakan tersebut dipelopori oleh Amir Syarifuddin dan Muso. Tujuan dari pemberontakan itu adalah untuk menghancurkan Negara RI dan menggantinya menjadi negara komunis. Beruntunglah pada saat itu Muso dan Amir Syarifuddin berhasil ditangkap dan kemudian ditembak mati sehingga pergerakan PKI dapat dikendalikan (Sucipto, 2013:42).

Pada bulan Juli 1959, Presiden Soekarno mengumumkan berlakunya demokrasi terpimpin. Tujuannya semula adalah untuk mengatasi pertentanganpertentangan yang tak berkesudahan dari partai-partai politik yang sudah ada. Partai Komunis Indonesia (P.K.I) dengan pintarnya memanfaatkan keadaan ini. Terlebih lagi dengan adanya ajaran dari presiden Soekarno tentang Nasakom (Nasional, Agama, Komunis) yang sangat menguntungkan $\mathrm{PKI}$ karena menempatkannya sebagai bagian yang sah dalam politik Indonesia. Hal ini hanya akan membukakan jalan bagi PKI untuk melancarkan rencana-rencananya. Yang salah satunya sudah terbukti adalah pemberontakan G-30-S-PKI yang dipimpin oleh DN.Aidit. Pemberontakan itu bertujuan untuk menyingkirkan TNI-AD sekaligus merebut kekuasaan pemerintahan (Sudirjo, 1977:1).

Sebenarnya pada saat itu keburukan PKI sudah akan terbongkar dengan ditemukannya dokumen-dokumen perjuangan PKI yang berjudul "Resume Program dan Kegiatan PKI Dewasa ini". Dalam dokumen tersebut nampak jelas disebutkan bahwa PKI akan melancarkan perebutan kekuasaan. Akan tetapi Ir. Soekarno tidak mempercayai hal itu dan tetap mendukung PKI (Adam, 2006:83).

Menurut Sudirjo, (1977:39-42) Selain karena ingin merebut kekuasaan, ada juga faktor lain yang membuat mereka melakukan pemberontakan itu, yakni :

Angkatan Darat Menolak Pembentukan Angkatan Kelima

Dalam rangka peningkatan pelaksanaan strategi dan taktiknya, PKI menuntut agar buruh dan tani dipersenjatai dengan kedok alasan mendukung 
konfrontasi dengan Malaysia. Gagasan ini ditolak oleh Jenderal Ahmad Yani, karena dengan adanya angkatan ke $\mathrm{V}$ jelas akan menimbulkan kekacauan di dalam komando dan pengawasan, di samping itu juga biayanya sangat besar (Sudirjo, 1977:41). Di dalam keterangannya kepada para wartawan pada tanggal 14 Januari 1965, Ketua D.N. Aidit mengatakan bahwa partainya menuntut kepada Pemerintah agar kaum buruh dan tani dipersenjatai. Tuntutan PKI itu ditampung oleh Front Nasional dan dirubah bentuknya sehingga seakan-akan tuntutan itu datangnya dari semua kekuatan politik yang ada pada waktu itu, melalui suatu pernyataan yang disebut "Kebulatan Tekad" (Sudharmono, 1985:20). Kebulatan tekad tersebut berbunyi antara lain:

"Menyerukan dan mendesak Pemerintah dan alat-alatnya yang berwenang untuk segera melatih dan mempersenjatai sokoguru-sokoguru revolusi, sebagai jaminan utama guna mencegah dan mengalahkan tiap bentuk agresi Inggris dan agresi Nekolim pada umumnya" (Sudharmono, 1985:20).

Angkatan Kelima adalah unsur pertahanan keamanan Republik Indonesia yang diduga merupakan gagasan Partai Komunis Indonesia (PKI). Angkatan Kelima ini diambil dari kalangan buruh dan petani yang dipersenjatai. Namun versi yang lain menyebutkan bahwa Angkatan Kelima sebenarnya merupakan ide dari Presiden Soekarno untuk menambah angkatan bersenjata di Indonesia karena menerima bantuan dari luar negri (Sucipto, 2013:109-110).

\section{Angkatan Darat Menolak Nasakomisasi}

Mulai tanggal 1 sampai dengan 10 Juni 1965 di berbagai tempat di seluruh Indonesia diadakan pendidikan kilat kader Nasakom. Pendidikan ini diselenggarakan oleh Front Nasional dan merupakan satu diantara berbagai usaha indoktrinasi (antara lain Kursus Kader Revolusi) yang dilakukan pada masa itu (Sucipto, 2013:33).

Adanya Nasakomisasi hanya akan menguntungkan kedudukan PKI untuk yang kesekian kalinya. ajaran nasakom, dilihat dari asal kata pembentukan katanya saja sudah ganjil, yakni "nasional, agama, komunis". Untuk kata nasional dan agama mungkin masih dapat kita cerna dengan baik. Akan tetapi untuk kata "komunis" membuat kita berfikir dua kali untuk menyetujui ajaran ini. Apalagi setelah banyaknya kerusuhan yang dilakukan partai ini hingga timbulnya korban jiwa. Keputusan TNI-AD memang sangat tepat menolak nasakomisasi tersebut (Sudirjo, 1977:39).

Dapat disumpulkan bahwa Nasakom singkatan dari Nasionalis-Agama-Komunis, adalah ajaran Bung Karno yang mengharuskan adanya persatuan "nasional progresif revolusioner" dengan ketiga golongan politik tersebut sebagai "poros"nya. Ajaran Nasakom ini oleh PKI diusahan harus diterapkan secara struktural, yaitu bahwa dalam setiap badan dan kegiatan negara, termasuk $A B R I$, golongan komunis harus diikutsertakan.

\section{Angkatan Darat Menolak Poros Jakarta- Peking}

Hal ini merupakan suatu langkah yang bijak menyangkut adanya Poros Jakarta-Peking hanya akan membantu Cina meluaskan semangat revolusi komunisnya di Asia Tenggara, dan akan merusak hubungan baik dengan negaranegara tetangga (Sudirjo, 1977:41).

Terjadi penyimpangan dari politik luar negeri bebas aktif yang menjadi cenderung condong pada salah satu poros. Saat itu Indonesia memberlakukan politik konfrontasi yang lebih mengarah pada negara-negara kapitalis seperti negara Eropa Barat dan Amerika Serikat. Politik konfrontasi tersebut dilandasi oleh pandangan tentang Nefo (New Emerging Forces) dan Oldefo (Old Established 
Forces) (Sudirjo,1977:41). Nefo merupakan kekuatan baru yang sedang muncul yaitu negara-negara progresif revolusioner (termasuk Indonesia dan negara-negara komunis umumnya) yang anti imperialisme dan kolonialisme (Sudirjo,1977:41). Oldefo merupakan kekuatan lama yang telah mapan yakni negara-negara kapitalis yang neokolonialis dan imperialis (Nekolim).

Untuk mewujudkan Nefo maka dibentuk poros Jakarta-Phnom PenhHanoi-Peking-Pyong Yang. Dampaknya ruang gerak Indonesia di forum internasional menjadi sempit sebab hanya berpedoman ke negara-negara komunis.

\section{Pemberontakan G30S/PKI}

Menjelang terjadinya peristiwa G.30.S/PKI, tersiar kabar bahwa kesehatan Presiden Soekarno menurun dan kemungkinan akan lumpuh atau meninggal. Mengetahui hal tersebut Dipa Nusantara Aidit langsung memulai gerakan. Rencana gerakan diserahkan kepada Kamaruzaman alias Syam yang diangkat sebagai ketua Biro Khusus Partai Komunis Indonesia (PKI) dan disetujui oleh Dipa Nusantara Aidit. Biro khusus ini menghubungi kadernya dikalangan Angkatan Bersenjata Republik Indonesia (ABRI) , seperti Brigadil Jenderal Supardjo, Letnan Kolonel Untung dari Cakrabirawa, Kolonel Sunardi dari Tentara Nasional Indonesia Angkatan Laut (TNI AL) , Marsekal Madya Omar Dani dari Angkatan Udara (AU) dan Kolonel Anwar dari Kepolisian. Menjelang pelaksanaan Gerakan 30 September 1965, pimpinan PKI telah beberapa kali mengadakan pertemuan rahasia. Tempat pertemuan terus berpindah dari satu tempat ke tempat yang lain. Kolonel Untung sebagai pemimpin dari Gerakan G.30.S/PKI tahun 1965, memerintahkan kepada seluruh anggota gerakan untuk siap dan mulai bergerak pada dini hari 1 Oktober 1965 untuk melakukan serangkaian penculikan dan pembunuhan terhadap 6 perwira tinggi dan seorang perwira pertama dari
Angkatan Darat dibunuh dan diculik dari tempat kediaman masing-masing, (Sucipto, 2013:112-114).

Menurut Sudharmono (1985:43) Pada tanggal 1 Oktober 1965 dini hari, PKI menculik dan membunuh para perwira yang dianggap menjadi perintang besar terhadap cita-citanya. PKI berhasil menculik perwira-perwira Angkatan Darat di Jakarta. Sebagian perwira tersebut dibunuh dirumahnya, yang lain mereka di aniaya, kemudian mereka di bunuh. Para perwira yang berhasil mereka culik dan dibunuh adalah :

\section{Penculikan dan Pembunuhan Terhadap Mayor Jendral Ahmad Yani}

Pasukan yang bertugas menculik Men/Pangad Letjend TNI A. Yani dipimpin oleh Mukidjan berangkat dari Lubang Buaya pukul 03.00 tanggal 1 Oktober 1965. Setiba di rumah Letjend TNI A.Yani di jalan Latuharhary 6 Jakarta, beberapa anggota penculik segera masuk pekarangan rumah. Regu pengawal yang sama sekali tidak menaruh curiga atas kedatangan mereka seketika itu dilucuti. Sebagian pasukan penculik menuju kekediaman Letjend A.Yani dan mengetuk pintu yang dibukakan oleh seorang pembantu, Isteri A. Yani malam itu sedang berada di kediaman resmi Men/Pangad di Taman Suropati. Sementara puteri kedua Letjend A. Yani terbangun mendengar adanya keributan, tetapi tidak berani keluar kamar, yang keluar dari kamarnya adalah putera beliau yang berumur 11 tahun, yang segera membangunkan ayahnya, dan beliaupun keluar dari kamarnya (Sucipto, 2013:139).

Dapat disimpulkan bahwa Letnan Jenderal A. Yani selalu berbeda paham dengan PKI. la menolak keinginan PKI untuk membentuk "Angkatan Kelima" yang terdiri dari kaum buruh dan tani yang dipersenjatai. Oleh karena itu, ia diduga sebagai salah satu target PKI yang diculik dan dibunuh. 


\section{Penculikan dan Pembunuhan Terhadap Mayor Jendral Suprapto}

Pasukan yang bertugas menculik Mayjend TNI Soeprapto dipimpin oleh Serda Sulaiman. Berangkat dari Lubang Buaya Tanggal 1 Oktober 1965 pukul 03.00. pasukan penculik ini memasuki halaman rumah Mayjend Soeprapto di jalan Besuki 19, Jakarta dan mengetuk pintu. Beliau terbangun dan setelah pasukan penculik menyatakan dari Cakrabirawa, beliau keluar dari kamarnya dan membuka pintu. Diteras sudah menunggu beberapa pasukan penculik. Serda Sulaiman mengatakan bahwa Mayjend Soeprapto diperintahkan untuk menghadap presiden dengan segera. Oleh beliau diperintahkan untuk menunggu karena akan berganti pakaian. Para penculik melarangnya dengan kasar, bahkan mendorong serta memaksanya keluar. Beberapa orang penculik memegangi tangannya dan menaikkannnya dengan paksa ke dalam sebuah truk, kemudian mereka kembali menuju ke Lubang Buaya (Sucipto, 2013:143).

Dapat disimpulkan bahwa beliau gugur sebagai Pahlawan Revolusi untuk mempertahankan Pancasila. Pangkatnya yang sebelumnya masih Mayor Jenderal dinaikan satu tingkat menjadi Letnan Jenderal sebagai Penghargaan atas jasajasanya.

\section{Penculikan dan Pembunuhan Terhadap Mayor Jendral S.Parman}

Pasukan yang bertugas menculik Mayjend TNI S. Parman dipimpin oleh Serma Satar. Berangkat dari Lubang Buaya Tanggal 1 Oktober 1965 pukul 03.00. pasukan penculik ini memasuki kediamannya di jalan Samsurizal 32, Jakarta. Mereka memasuki pekarangan rumah dengan melompat pagar. Karena keributan itu Mayjend S. Parman terbangun dan menduga ada perampokan di rumah tetangganya. Beliau keluar kamar dengan maksud memberi bantuan ketika membuka pintu depan, di luar telah menunggu para penculik yang mengatakan bahwa beliau dipanggil oleh presiden. Beliau mengatakan akan memenuhi panggilan tersebut dan kembali ke kamarnya untuk berganti pakaian. Dua orang penculik mengikutinya dari belakang. Beliau minta agar mereka menunggu di ruang tengah saja, tetapi mereka tidak mengindahkannya (Sucipto, 2013:144).

Istri S. Parman mulai curiga akan tingkah laku mereka yang demikian kasar. Beliau menanyakan surat perintah panggilan dari Istana Presiden, seorang menjawab bahwa surat perintah tersebut ada pada Pelda Yanto di luar. Usaha Ny. S. Parman untuk melihat surat perintah tersebut tidak berhasil. Karena surat perintah itu memang tidak pernah ada. Bahkan beliau ditodong dengan sangkur. Dengan berpakaian lengkap Mayjend $S$. Parman keluar kamar, sambil melangkah beliau meminta kepada istrinya agar menelpon Letjend A. Yani, untuk melaporkan kejadian tersebut. Ternayata kabel telepon telah diputus. Mayjend S. Parman dimasukkan ke dalam kendaraan pasukan penculik dan dibawa ke Lubang Buaya (Sucipto, 2013:146).

Kejadian di atas disebabkan karena PKI mengusulkan agar kaum buruh dan tani dipersenjatai atau yang disebut Angkatan Kelima. la bersama sebagian Perwira Angkatan Darat lainnya menolak usul tersebut.

\section{Penculikan dan Pembunuhan Terhadap Mayor Jendral M.T. Haryono}

Pasukan yang bertugas menculik Mayjend TNI Haryono dipimpin oleh Serma Bungkus. Berangkat dari Lubang Buaya Tanggal 1 Oktober 1965 pukul 03.00. setibanya di kediaman Mayjend Haryono di jalan Pramabanan 8, Jakarta. Serma Bungkus memberi tahu Ny. Haryono bahwa Mayjend Haryono dipanggil oleh presiden. Ny. Haryono yang tidak menaruh curiga kepada mereka kemudian membangunkan 
Mayjend Haryono, beliau menaruh curiga dan melaui isterinya beliau meminta agar kembali lagi sekitar pukul 08.00. Serma Bungkus memaksa agar beliau berangkat pada malam itu juga. Karena menyadari sesuatu hal yang tidak wajar beliau meminta kepada isteri dan anak-anaknya pindah ke kamar sebelah. Sementar itu Serma bungkus dan beberapa anggota penculik berteriak-teriak meminta agar beliau keluar (Sucipto, 2013:146-147).

Karena beliau tidak memenuhi permintaan tersebut, mereka melepaskan tembakan ke pintu yang terkunci. Pintu terbuka dan mereka memasuki kamar tidur. Pada saat beliau berusaha merebut senjata salah seorang anggota penculik, tetapi gagal dan bersamaan dengan itu beliau ditusuk beberapa kali dengan sangkur. Beliau roboh bermandikan darah dan kemudian diseret keluar dan dimasukkan kedalam truk lalu kembali ke lubang buaya (Sucipto, 2013:148).

\section{Penculikan dan Pembunuhan Terhadap Brigadir Jendral D.I Panjaitan}

Pasukan yang bertugas menculik Brigjend dipimpin oleh Serda Sukardjo. Berangkat dari Lubang Buaya tanggal 1 Oktober 1965 pukul 03.00. para penculik membuka pintu kediamannya yang berada di Jalan Hasanudin 53 Jakarta dengan paksa, kemudian menembak kedua keponakan beliau yang saat itu sedang tidur di lantai atas. Salah seorang diantaranya tewas, setelah itu para penculik berteriak memanggil Brigjend D.I Panjaitan agar keluar untuk menghadap Presiden. Semula beliau tidak mau keluar, tetapi karena adanya ancaman dari para penculik yang akan membunuh seisi rumah jika tidak mau keluar, maka beliau keluar dan menuruni tangga dengan mengenakan pakaian seragam lengkap (Sucipto, 2013:150).

Setiba di halaman, beliau tidak dapat menahan amarahnya atas sikap para anggota pasukan penculik terhadapnya.
Beliau dipukul dengan popor senjata hingga jatuh. Pada saat itu juga dua orang anggota penculik yang lain menembaknya dengan senjata otomatis. D.I Panjaitan gugur pada saat itu juga dan jenazahnya dimasukkan dalam satu kendaraan yang telah disediakan. Sementara itu, seorang anggota polisi berpangkat agen polisi (Bharada) Sukitman yang sedang melaksanakan tugas patroli, karena mendengar letusan senjata api, mendatangi tempat kejadian. Setibanya ditempat itu ia langsung ditangkap oleh para penculik dan ikut dibawa pula ke Lubang Buaya (Sucipto, 2013:151).

\section{Penculikan dan Pembunuhan Terhadap Brigadir Jendral Sutoyo Siswomiharjo}

Pasukan yang bertugas menculik Brigjen TNI Sutojo dipimpin oleh Serma Surono. Berangkat dari Lubang Buaya Tanggal 1 Oktober 1965 pukul 03.00. Sebagian anggota penculik memasuki bagian belakang rumah kediaman beliau di jalan Sumenep 17, Jakarta melalui garasi sebelah kanan. Dengan todongan sangkur mereka meminta kepada pembantu untuk menyerahkan kunci pintu yang menuju ke kamar tengah, setelah membuka pintu, penculik menerobos masuk dan mngatakan kepada Brigjend Sutojo, bahwa beliau dipanggil Presiden, kemudian para penculik membawa beliau dengan paksa keluar rumah dan membawanya ke Lubang Buaya (Sucipto, 2013:151).

Mayor Jenderal Sutoyo Siswomiharjo adalah Pahlawan Revolusi yang difitnah PKI akan membentuk dewan jenderal dan akan mengadakan kudeta militer terhadap kepemimpinan Presiden Soekarno. Fitnah tersebut yang menjadi alasan PKI menculik dan membunuh beliau.

PKI juga berusaha menculik Jendral A.H. Nasution, usaha mereka gagal karena Jendral A.H. Nasution dapat meloloskan diri dari kepungan. Namun, putri Jendral A.H. Nasution, Ade Irma Suryani Nasution dan Letnan Piere Tendean, ajudan Jendral 
A.H. Nasution dan Brigadir Polisi Karel Satsuit Tubun telah menjadi korban.

Di Yogyakarta, PKI juga mengadakan aksi. PKI telah membunuh Kolonel Katamso Dharmokusumo dan Letnan Kolonel Sugiyono Mangunwiyoto. Pembunuhan dilakukan dengan cara kejam. Sebelumnya, para perwira Pancasila itu disiksa dengan keji. Jenazahnya diseret dan dibuang ke dalam sumur di Lubang Buaya (Sudharmono 1985:43)

Menurut Sudirjo, (1977:57) tanggal 30 September 1965 lewat tengah malam, terjadi penculikan dan pembunuhan atas beberapa orang perwira tinggi Tentara Nasional Indonesia Angkatan Darat (TNI AD). Penculikan dan pembunuhan itu dilakukan oleh Cakrabirawa dan satuan lainnya yang pro-PKI, yang dipimpin oleh Letnan Kolonel Untung. Selain itu, gedung Telekomunikasi dan Radio Republik Indonesia (RRI) Pusat diduduki. Gerakan 30 September/Partai Komunis Indonesia merupakan sebuah pemberontakan yang mengambil alih gerakan pengamanan Presiden atau Panglima Tinggi Angkatan Bersenjata Republik Indonesia dari coup "Dewan Jenderal" Namun, Pancasila telah memperlihatkan kesaktiannya. Hanya 1 hari G.30.S dan PKI sanggup bertahan di Ibu kota. Tanggal 2 Oktober seluruh lbu kota berikut kompleks Lapangan Udara Halim Perdana Kusuma telah dapat dibersihkan dari satuan-satuan pemberontakan, berkat kesigapan pimpinan dan pasukan-pasukan Tentara Nasional Indonesia Angkatan Darat dan kerjasama antar rakyat dengan angkatanangkatan yang setia terhadap Pancasila.

\section{Tindakan Penumpasan G30S/PKI}

Menurut Sudirjo, (1977:6) operasi penumpasan G.30.S/PKI dilancarkan pada hari Jumat tanggal 1 Oktober 1965. Mayor Jenderal Soeharto yang menjabat Panglima Komando Strategis Angkatan Darat (Kostrad) mengambil alih Komando
Angkatan Darat. Di bawah pimpinan Kolonel Sarwo Edhi Wibowo Studio Radio Republik Indonesia (RRI) pusat, gedung besar telekomunikasi dapat direbut kembali, serta penangkapan terhadap pemberontakan.

Sudharmono, (1985:46) dalam minggu pertama bulan Oktober 1965 rakyat Indonesia dikejutkan oleh serangakaian berita Radio Republik Indonesia (RRI) Jakarta tentang terjadinya pergolakan pada tingkat tertinggi pemerintahan ibukota Jakarta. Pada hari Jum'at tanggal 1 Oktober 1965 secara berturut-turut RRI Jakarta menyiarkan empat berita penting. Siaran pertama, sekitar pukul 07.00 pagi, memuat berita bahwa pada hari Kamis tanggal 30 September 1965 di lbukota Republik Indonesia, Jakarta telah terjadi "gerakan militer dalam Angkatan Darat" yang dinamakan "Gerakan 30 September", dipimpin oleh Letkol Untung, Komandan Bataliyon Cakrabirawa, pengawal pribadi Presiden Soekarno. Sejumlah besar Jenderal telah ditangkap, alat-alat komunikasi yang penting-penting serta obyek penting lainnya sudah dikuasai Gerakan tersebut dan "Presiden Soekarno selamat dalam lindungan Gerakan 30 September". Gerakan tersebut ditujukan kepada Jenderal-jenderal anggota apa yang menamakan dirinya Dewan Jenderal. Komandan Gerakan 30 Sepetember itu menerangkan bahwa akan dibentuk Dewan Revolusi Indonesia ditingkat pusat yang dikuti oleh tingkat kabupaten, kecamatan dan desa.

Menurut Sudharmono, (1985:46-47) siaran kedua, sekitar pukul 13.00 hari itu juga memberitakan "Dekrit No.1 tentang Pembentukan Dewan Revolusi Indonesia dan keputusan No.1 tentang susunan Dewan Revolusi Indonesia". Baru dalam siaran kedua ini diumumkan "Komando Gerakan 30 September", yaitu Letnan Kolonel Untung sebagai komandan dengan wakil ketua Brigadir Jenderal Supardjo, Letnan Kolonel (Udara) Heru, Kolonel 
(Laut) Sunardi, dan ajun komisaris besar polisi anwas sebagai wakil komandan. Keputusan kedua mengenai penghapusan pangkat Jenderal dan mengenai pangkat yang tertinggi dalam $A B R I$ letnan kolonel. Mereka yang berpangkat di atas letnan kolonel harus menyatakan kesetiaanya kepada Dewan Revolusi, untuk selanjutnya baru berhak memakai tanda pangkat letnan kolonel. sedangkan bintara dan tamtama $A B R I$ yang ikut melaksanakan Gerakan 30 September, pangkatnya dinaikan satu tingkat dan yang ikut gerakan pembersih "Dewan Jenderal" dinaikan dua tingkat.

Pada saat-saat genting sekitar bulan September 1965 muncul isu adanya Dewan Jenderal, yang mengungkapkan bahwa para petinggi Angkatan Darat tidak puas terhadap Soekarno dan berniat untuk menggulingkannya. Menanggapi isu ini, Soekarno memerintahkan pasukan Cakrabirawa untuk menangkap dan membawa mereka untuk diadili. Namun secara tak terduga, dalam operasi penangkapan tersebut para jenderal tersebut terbunuh (Sucipto, 2013:114). Menurut Sudharmono, (1985:47-48) siaran ketiga, pada pukul 19.00, RRI menyiarkan pidato radio Panglima Komando Cadangan Strategis Angkatan Darat (Kostrad), Mayor Jenderal Soeharto, yang menyampaikan bahwa gerakan 30 September tersebut adalah golongan kontra revolusioner, yang telah menculik beberapa perwira tinggi angkatan darat, dan telah mengambil alih kekuasaan negara. Dengan prosedur tetap angkatan darat, Mayor Jendral Soeharto mengumumkan bahwa untuk sementara pimpinan Angkatan Darat dipegang oleh beliau.

\section{Penumpasan G30S/PKI di Jawa Tengah}

Menurut Sudirjo, (1977:80) di Jawa Tengah terdapat kekuatan massa Partai Komunis Indonesia yang besar sekali, dan terdapat sejumlah besar Perwira Tentara Nasional Indonesia Angkatan Darat yang telah berhasil dibina oleh Biro Khusus PKI semenjak beberapa tahun sebelum terjadinya pemberontakan. Setelah pimpinan pemberontakan PKI mengalami kegagalan dengan diserbunya Lapangan Udara Halim Perdana Kusuma oleh satuan Resimen Para Komando Angkatan Darat dan Panglima Komando Strategis Angkatan Darat pada tanggal 2 Oktober 1965, diputuskan untuk segera meninggalkan Lapangan Udara Halim Perdana Kusuma. Di Jawa Tengah Aidit bersama teman-temannya bermaksud akan meneruskan petualangannya secara gerilya. Untuk mengejar gembonggembong G30S/PKI ini, pimpinan Angkatan Darat telah mengerahkan satuan-satuan Resimen Para Komando Angkatan Darat yang dipimpin oleh Kolonel Edhie Wibowo. Ternyata misi yang dilakukan oleh Angkatan Darat berhasil baik berkat kerjasama dan bantuan rakyat Jawa Tengah. Perlawanan Aidit, Ir. Sakirman, Letnan Kolonel Usman dan tokoh-tokoh pemberontak lainnya dapat dihancurkan dalam waktu yang singkat.

Pemberontakan PKI dengan Gerakan 30 Septembernya ternyata telah matang dipersiapkan dan tidak terbatas hanya di Jakarta saja. Di berbagai daerah, PKI dan anggota-anggota ABRI yang telah dibina oleh PKI melakukan perebutan kekuasaan. Berdirinya Dewan Revolusi di Yogyakarta diumumkan melalui RRI (Radio Republik Indonesia) pada tanggal 1 Oktober 1965. Dewan Revolusi di daerah Yogyakarta diketuai oleh Mayor Mulyono, kepala seksi Teritorial Korem 072/Yogyakarta. Komandan Korem 072, Kolonel Katamso dan Kepala Staf Korem 072 Letnan kolonel Sugiyono, masingmasing diculik dari rumah dan markas Korem 072 pada sore hari tanggal 1 Oktober 1965 (Sudharmono, 1985:48).

\section{Pemulihan Keamanan dan Ketertiban dari Pemberontakan G30S/PKI}

Sore hari tanggal 2 Oktober 1965 setelah berhasil menguasai kembali 
kekuasaan kota Jakarta, Mayend Soeharto menemui Presiden di Istana Bogor. Dalam pertemuan tersebut presiden memutuskan untuk secra langsung memegang tampuk Pimpinan Angkatan Darat yang semenjak tanggak 1 Oktober 1965 untuk sementara Mayjend. Soeharto. Sebagai pelaksana harian presiden menunjuk Mayjend Pranoto Reksosamudro untuk menyelenggarakan pemulihan keamanan dan ketertiban seperti sedia kala ditunjuk Mayjend Soeharto, panglima Kostrad (Sudharmono, 1985:51).

Keputusan tersebut disiarkan oleh Presiden dalam Pidato melalui RRI Pusat dini hari pukul 01.30 tanggal 3 Oktober 1965. Pengangkatan Mayjend Soeharto sebagai panglima operasi pemulihan keamanan dan ketertiban serta pembentukan Komando operasi pemulihan keamanan dan ketertiban (Kopkamtib) kemudian diatur dengan Kepres/Pangti ABRI/Koti Nomor 142/Koti/1965 tanggal 1 November 1965, Nomor 162/Koti/1965/ tanggal 12 November 1965 dan Nomor 179/Koti/1965 tanggal 6 Desember 1965 (Sudharmono, 1985:51).

Tugas pokok Kopkamtib adalah memulihkan keamanan dan ketertiban dari akibat-akibat peristiwa Gerakan 30 September serta menegakkan kembali kewibawaan pemerintah pada umumnya dengan jalan operasi fisik, militer dan mental. Dalam usaha penumpasan gerakan pemberontakan ini, di mana-mana $\mathrm{ABR}$ mendapat bantuan dari rakyat dan bekerjasama dengan organisai-organisasi politik dan organisasi-organisasi masa yang setia kepada pancasila (Sudharmono, 1985:51).

Menurut Sudharmono, (1985:60) pembersihan sisa-sisa Gerakan 30 September terus dilanjutkan. Seorang demi seorang tokoh-tokoh G.30.S/PKI dapat ditangkap, antara lain Kolonel Latief, bekas Komandan Brigadir Infantri I atau Kodam V Jaya, berhasil ditangkap pada tanggal 9 Oktober 1965. Dua hari kemudian, pada tanggal 11 Oktober 1965, ditangkap pula Letnan Kolonel Untung yang berusaha melarikan diri.

Menurut Sudirjo,

berdasarkan wewenang yang bersumber pada Supersemar, Letnan Jenderal Soeharto atas nama Presiden menetapkan pembubaran dan pelarangan PKI, termasuk semua bagian-bagian organisasinya dari tingkat pusat sampai ke daerah beserta semua organisasi yang berlindung/bernaung di bawahnya, keputusan tersebut dituangkan dalam Keputusan Presiden/Pangti ABRI/mandataris MPR/PBR no.1/3/1966 tanggal 12 Maret 1966 dan merupakan tindakan pertama Letnan Jenderal Soeharto sebagai pengembangan perintah 11 Maret atau Supersemar. Keputusan pembubaran dan pelarangan $\mathrm{PKI}$ itu diambil oleh pengembangan Supersemar berdasarkan pertimbangan bahwa PKI telah nyata-nyata melakukan perbuatan kejahatan dan kekejaman. Bukan itu saja, tetapi telah dua kali pengkhianatan terhadap negara dan rakyat Indonesia yang sedanag berjuang. Seluruh rakyat yang menjunjung tinggi landasan falsafah dan ideologi Pancasila waktu itu serentak menuntut dibubarkannya PKI. Oleh karena itu, keputusan pembubaran PKI itu disambut dengan gembira dan perasaan lega oleh seluruh rakyat Indonesia.

Pada tanggal 11 Maret 1966 Presiden mengeluarkan surat perintah kepada Letjen Soeharto, menteri/pangad, yang pokoknya berisi perintah kepada Letjen Soeharto untuk atas nama presiden/Pangti ABRI/peminpim besar Revolusi, mengambil segala tindakan yang dianggap perlu guna terjaminnya keamanan dan ketenangan serta kesetabilam pemerintahan (Sudharmono,1985:89).

\section{Peranan Soeharto dalam Penumpasan G30S/PKI}

Mayor Jenderal Soeharto, Panglima Komando Strategis Angkatan Darat, pada 
tanggal 2 Oktober diberi tugas untuk memulihkan keamanan dan ketertiban. Dengan keputusan Presiden No. 142/KOTI/1965 Tanggal 1 November 1965, penugasan tersebut lebih dipertegas dengan pengangkatan sebagai Panglima Operasi Pemulihan Keamanan dan Ketertiban, (Sudharmono,1985:52). Soeharto menyusun rencana untuk menumpas gerakan pengkhiatan tersebut. Beliau segera mengkonsolidasikan dan menggerakkan personil Markas Komando Strategis Angkatan Darat dan satuansatuan lain di Jakarta yang tidak mendukung Gerakan 30 September, disertai dengan usaha menginsyafkan kesatuan-kesatuan yang digunakan oleh Gerakan 30 September. Setelah pasukanpasukan yang di pengaruhi oleh G.30.S/PKI berhasil disadarkan, maka langkah selanjutnya adalah merebut Radio Republik Indonesia di Jakarta dan Kantor Besar Telkom yang sejak pagi-pagi diduduki oleh pasukan Kapten Infantri Suradi yang berada dibawah komando Kolonel Infantri A. Latief (Gayo, 2013:92) .

Untuk mengisi kekosongan pimpinan Angkatan Darat pada tanggal 14 Oktober 1965 Mayor Jenderal Soeharto diangkat sebagai mentri atau Panglima Angkatan Darat. Pelantikan Mayor Jenderal Soeharto sebagai Men/Pangad dilakukan oleh Presiden Soekarno pada tanggal 16 Oktober 1965 di Istana Negara (Sudharmono,1985:64). Beberapa hari sebelum kedudukannya sebagai Panglima Operasi Pemulihan Keamanan dan Ketertiban Mayor Jenderal Soeharto telah mengeluarkan seruan kepada seluruh rakyat Indonesia untuk meningkatkan keamanan di lingkungan wilayah masingmasing, mengamankan alat-alat produksi, distribusi, dan komunikasi, menumpas gerombolan petualangan G $30 \mathrm{~S}$, dan meningkatkan semangat/aksi pengganyangan unsur-unsur kontra revolusi.
Lima bulan setelah itu, pada tanggal 11 Maret 1966, Sukarno memberi Suharto kekuasaan tak terbatas melalui Surat Perintah Sebelas Maret. la memerintah Suharto untuk mengambil "langkah-langkah yang sesuai" untuk mengembalikan ketenangan dan untuk melindungi keamanan pribadi dan wibawanya. Kekuatan tak terbatas ini pertama kali digunakan oleh Soeharto untuk melarang PKI. Kepemimpinan PKI terus mengimbau massa agar menuruti kewenangan rejim Soekarno-Soeharto. Aidit, yang telah melarikan diri, ditangkap dan dibunuh oleh TNI pada tanggal 24 November, tetapi pekerjaannya diteruskan oleh Sekretaris Kedua PKI, Nyoto. Karena situasi politik yang memburuk setelah meletusnya G-30S/PKI, Sidang Istimewa MPRS, Maret 1967, menunjuk Pak Harto sebagai Pejabat Presiden, dikukuhkan selaku Presiden RI Kedua, Maret 1968 (Sudharmono,1985:105).

\section{Kontroversi keterlibatan Soeharto dalam Penumpasan G30S/PKI 1965}

Saat ini keterlibatan Soeharto banyak dipertanyakan, sehingga keterlibatannya menjadi kontroversi. Namun adapun pengakuan Kol. A. Latief (gembong PKI) bahwa dua kali ia memberitahukan kepada Soeharto tentang rencana penindakan terhadap sejumlah Jenderal. Dalam bahasa laten menghadapkan Dewan Jenderal kepada Presiden. Namun Soeharto yang pada saat itu menjadi Panglima Kostrad tidak mengambil inisiatif melapor kepada atasannya. Dia diam saja dan hanya manggut-manggut mendengar laporan itu (Sucipto, 2013:110).

Fakta bahwa sebagai perwira tinggi dengan fungsi pemandu di bawah Pangab Jenderal A. Yani, Soeharto tidak termasuk sasaran G 30 S/PKI. Ini bisa dipertanyakan, mengingat strategisnya posisi Kostrad apabila negara dalam keadaan bahaya. Jika betul Soeharto tidak berada dalam 
inner circle gerakan, kemungkinan besar ia termasuk dalam daftar korban penculikan. Adapun fakta-fakta lain yang mampu mengungkap kebenaran ini, tidak hanya sebatas fakta internal. Lebih dari itu kebenaran yang mulai terkuak dan amat mengejutkan masyarakat awam adalah ternyata Soeharto juga mempunyai hubungan dengan CIA. Hal ini terbukti dengan adanya satu kompi batalyon 454 Diponegoro Jawa Tengah dan satu kompi batalyon 530 Brawijaya Jawa Timur, yang secara terselubung digunakan Soeharto sebagai penggerak (Sucipto, 2013:112). Soeharto disebut-sebut terlibat dalam peristiwa tragis itu. Oleh saksi dan sejumlah pelaku sejarah, serta sejarawan, dikatakan Soeharto mengetahui rencana penculikan para Jenderal. Tapi, tidak berusaha mencegahnya. Itulah salah satu titik kontroversi yang dimuat dalam buku 44 Tahun G.30.S/PKI, Antara Fakta dan Rekayasa yang terbit tahun 1999 (Sucipto, 2013:113).

\section{SIMPULAN}

1. Soeharto memiliki peranan yang besar dalam perjuangan mempertahankan kemerdekaan Indonesia. Salah satu peranan Soeharto adalah dalam Peristiwa Gerakan 30 September 1965. Soeharto merupakan seseorang yang berperan penting dalam Gerakan 30 September 1965.

2. Dengan bantuan Pahlawan Revolusi dan rakyat Indonesia yang setia pada Pancasila maka Gerakan 30 September dapat ditumpas dan orang-orang yang beraliran PKI (Partai Komunis Indonesia) dapat mempertanggung jawabkan perbuatannya. Dengan berakhirnya Gerakan 30 September, berakhir pula rakyat Indonesia yang dijajah dan disiksa secara keji demi suatu kedudukan atau kepemimpinan.
3. Gerakan 30 September 1965 mempunyai makna besar bagi keberadaan Indonesia. Gerakan 30 September juga merupakan suatu pembuktian terhadap dunia internasional bahwa Indonesia merupakan negara yang kuat. Terbukti dengan adanya eksistensi Tentara Nasional Indonesia dalam mempertahankan Negara Republik Indonesia.

\section{DAFTAR PUSTAKA}

Adam, Asvi Warman. 2006. Sisi Gelap Sejarah Indonesia. Yogyakarta: Ombak.

Gayo, Iwan. 2013. Buku Pintar Seri Junior. Jakarta Selatan: Pustaka Warga Negara.

Margono, S. 2009. Metodologi Penelitian Pendidikan. Jakarta: Rineka Cipta.

Pambudi, A. 2006. SUPERSEMAR. Yogyakarta: Media Pressindo.

Priyadi, Sugeng. 2012. Sejarah Lokal. Konsep, Metode dan Tantangannya. Yogyakarta: Ombak.

Roeder. 1987. Anak Desa, Biografi Presiden Soeharto. Jakarta: Gunung Agung.

Samsudin. 2004. Mengapa G30S/PKI Gagal?. Jakarta: Yayasan Obor Indonesia.

Sucipto, Dwi Herman. 2013. Kontroversi G30S. Yogyakarta: Palapa.

Sudharmono. 1985. 30 Tahun Indonesia Merdeka. Jakarta: Gita Karya.

Sudirjo, Radik Utoyo. 1977. Supersemar (Surat Perintah Sebelas Maret). Jakarta : Departemen Penerangan R.I Direktorat Penerangan Rakyat. 